\title{
ANNOUNCEMENT
}

9th International Congress of Biorheology

and

2nd International Conference on Clinical Haemorheology

23-28 July, 1995

Big Sky, Montana, USA

\section{Preliminary Programme}

Plenary Lectures

D. Brooks

Y.-C. Fung

Current models of red blood cell aggregation

D. Hammer

Rheology of soft tissue

R. Hochmuth

Cell-cell adhesive interactions

M. Kaibara

White blood cell mechanics

G. Lowe

Rheology of blood coagulation

Hemorheology and cardiovascular risk

Symposia (selected - clinical/therapy)

Cancer cell adhesion, migration and metastasis (P.Sung)

Cerbral vascular disease (M.Fisher/B.Coull)

Fibrinogen, hemorheology and cardiovascular disease(E.Ernst)

Guidelines for clinical trials and laboratory methodology (J.Stuart)

Hemodilution and hypertonic-hyperoncotic solutions (W.Kroll)

Hemolytic anemias (A.Schechter/C.Noguchi)

Heparin-induced LDL precipitation therapy (M.Wlazl)

Hyperlipidemia (A.Vaya)

Microcirculation and rheological factors during ischemia (M.Boisseau)

Molecular mechanisms of abnormal blood cell adhesion (B.Cooke/T. Wick)

Mucolysis in lung disease (M.King)

Myocardial infarction (K.Toth)

Rheological factors in pathology of peripheral vascular disease (G.Lowe/G.Nash)

Further information, registration etc.

Big Sky 1995 Meeting

Dept. Biophysics

University of Rochester Medical Center

601 Elmwood Avenue

Rochester, NY 14642-8431 USA 